\title{
Pengembangan Model Jaringan Syaraf Tiruan untuk Menduga Emisi Gas Metana dari Padi Sawah
}

\author{
Developing Artificial Neural Networks Model to Estimate Methane \\ Gas Emission from Paddy Fields
}

\author{
CHUSNUL ARIF $^{1 *}$, BUDI INDRA SETIAWAN ${ }^{1}$, SLAMET WIDODO $^{2}$, RUDIYANTO $^{1}$, \\ NUR AINI ISWATI HASANAH ${ }^{1}$, NURFAIJAH ${ }^{1}$, OKTARI EGA $^{1}$, MASARU \\ MIZOGUCHI $^{3}$
}

\begin{abstract}
Abstrak
Budidaya padi sawah dengan sistem irigasi tergenang merupakan sumber emisi gas metana $\left(\mathrm{CH}_{4}\right)$ yang menyebabkan peningkatan pemanasan global. Pada umumnya, pengukuran gas metana dilakukan secara tidak kontinu dengan melakukan sampling dan analisis di lab menggunakan gas chromatography yang cukup mahal. Makalah ini menyajikan model jaringan syaraf tiruan (JST) untuk memprediksi gas metana yang diemisikan dari padi sawah berdasarkan data parameter lingkungan biofisik yang mudah diukur seperti kelembaban tanah, suhu tanah, dan daya hantar listrik (DHL) tanah. Untuk melakukan validasi model, percobaan dilakukan di dua tempat berbeda yaitu di Kanagawa dan Bogor. Perlakuan difokuskan pada pemberian air yang berbeda dengan menggunakan prinsip budidaya system of rice intensification (SRI). Model JST yang dikembangkan menggunakan algoritma back propagation dengan layer masukan terdiri atas 3 node: kelembaban tanah, suhu tanah, dan DHL tanah, sedangkan gas metana dijadikan sebagai keluaran. Dari hasil pembelajaran model JST didapatkan korelasi antara gas metana hasil pengukuran dan model cukup tinggi dengan nilai $R^{2}$ sebesar 0.93 .
\end{abstract}

Kata kunci: emisi gas rumah kaca, gas metana, jaringan syaraf tiruan, lingkungan biofisik, padi sawah

\begin{abstract}
Conventional paddy field with continuous flooding irrigation is a major source of methane emission which contributes to global warming. Commonly, it is measured manually using closed chamber that is placed over some paddies rice. Then, the gas sample is taken from the chamber periodically and the gas sampling is analyzed using a gas chromatograph in the lab. The method is time consuming and complicated with more expensive equipments. The current study proposes artificial neural networks (ANN) model to predict methane emission from paddy field based on environmental biophysics parameters that are easily measured such as soil moisture, soil temperature, and soil electrical conductivity (EC). To verify the model, two experiments were conducted in two different locations: Kanagawa and Bogor. Each treatment focuses on different water irrigation regime adopted system of rice intensification (SRI) cultivation. ANN model was developed using back propagation algorithms. There were three nodes of input consisted of soil moisture, soil temperature, and soil $(E C)$. Meanwhile, methane emission was used as output. The result showed that estimated methane emission was close to measured emission with $R^{2}$ of 0.93 .
\end{abstract}

Keywords: artificial neural networks, greenhouse gas emissions, paddy fields, soil moisture, soil temperature, soil electrical conductivity.

\footnotetext{
${ }^{1}$ Departemen Teknik Sipil dan Lingkungan, Institut Pertanian Bogor;

${ }^{2}$ Departemen Teknik Mesin dan Biosistem, Institut Pertanian Bogor;

${ }^{3}$ Department of Global Agricultural Sciences, the University of Tokyo, Japan

*Penulis Korespondensi: Tel/Faks: 0251-8627225; Surel: chusnul_arif@ipb.ac.id
} 


\section{PENDAHULUAN}

Pemanasan global telah menjadi isu utama saat ini karena telah mempengaruhi perubahan iklim. Pemanasan global terjadi karena emisi dari gas-gas rumah kaca dalam jumlah yang cukup besar. Emisi gas-gas rumah kaca tersebut terjadi sebagai akibat dari aktivitas manusia di berbagai bidang termasuk bidang pertanian seperti budidaya padi sawah dengan irigasi tergenang. Budidaya tersebut menyumbangkan emisi gas rumah kaca yang cukup besar khususnya gas metana $\left(\mathrm{CH}_{4}\right)$ yang merupakan salah satu gas rumah kaca yang memiliki potensi 23 kali lebih besar dari gas $\mathrm{CO}_{2}$ (Snyder et al. 2007). Global Methane Initiative memprediksi pada tahun 2010 budidaya padi sawah menyumbangkan emisi gas metana sebanyak $10 \%$ dari seluruh aktifitas manusia.

Gas metana terbentuk dari dekomposisi bahan organik pada kondisi anaerobik seperti terjadinya genangan pada lahan sawah. Pada kondisi tersebut, mikroorganisme berupa bakteri metanogenik sangat aktif yang mendorong terbentuknya gas metana. Oleh sebab itu, salah satu cara mengurangi emisi gas metana dari padi sawah adalah dengan melakukan irigasi berselang melalui budidaya padi sawah alternatif dengan system of rice intensification (SRI). Terbukti cara tersebut mampu mengurangi emisi gas metana sebesar 32\% (Rajakishore et al. 2013).

Pada umumnya pengukuran gas metana dilakukan secara tidak kontinu dengan melakukan sampling dan analisis di lab menggunakan gas chromatography yang cukup mahal. Sampling gas diambil pada waktu tertentu (umumnya siang hari) dan kemudian diakumulasikan nilai hariannya. Cara ini cukup memakan waktu dan membutuhkan biaya yang tidak sedikit untuk analisis gas metananya. Selain itu, kondisi lingkungan biofisik sawah yang dinamis mengakibatkan emisi gas metana juga akan dinamis, sehingga pengambilan sampling gas di siang hari tentu tidak dapat mewakili kondisi malam hari. Hal ini mengindikasikan terdapat potensi kesalahan perhitungan akumulasi gas metana harian disebabkan pengambilan sampling gas yang tidak kontinu tersebut.

Untuk itu, makalah ini menyajikan alternatif metode untuk memprediksi emisi gas metana berdasarkan kondisi lingkungan biofisik yang mudah diukur dengan sensor tertentu. Emisi gas metana sangat dipengaruhi oleh kondisi lingkungan biofisik di dalam tanah seperti kelembaban tanah, suhu tanah, daya hantar listrik (DHL) tanah, $\mathrm{pH}$ tanah, dan redoks potensial tanah. Akan tetapi hubungan antara emisi gas metana dan parameter biofisik tersebut sangat kompleks dan sulit dimodelkan dalam persamaan matematika. Oleh sebab itu, model jaringan syaraf tiruan (JST) digunakan untuk memodelkan hubungan antara emisi gas metana dan parameter biofisik didalam tanah tersebut.

Model JST lebih cocok digunakan untuk memodelkan sistem yang komplek seperti pada bidang pertanian daripada model matematika (Hashimoto 1997). Model JST memiliki kemampuan untuk mengenali dan mempelajari hubungan input dan output dari sistem tanpa memperhatikan kondisi fisiknya secara eksplisit (Basheer dan Harmeer 2000). Pada bidang pertanian khususnya bidang aplikasi irigasi, model JST telah digunakan untuk rencana strategi dan klasifikasi irigasi (Raju et al. 2006) dan memprediksi tingkat pembasahan dari subpermukaan untuk irigasi tetes (Hinnell et al. 2009).

Setiawan et al. (2013) telah mengembangkan model JST untuk memprediksi gas metana dan dinitrogen oksida $\left(\mathrm{N}_{2} \mathrm{O}\right)$ berdasarkan parameter lingkungan biofisik yang terdiri dari kelembaban tanah, suhu tanah, dan $\mathrm{pH}$ tanah. Hasilnya menunjukkan bahwa model JST dapat memprediksi emisi gas metana dan dinitrogen oksida dengan nilai koefisien determinasi $\left(R^{2}\right)$ berturut-turut sebesar 0.72 dan 0.69 . Hal ini menunjukkan model JST dapat digunakan untuk memprediksi gas metana dan nitrous oksida dengan baik. Akan tetapi, untuk parameter $\mathrm{pH}$ tanah juga tidak mudah diukur secara kontinu karena sensor yang digunakan berbeda dan terpisah dengan sensor kelembaban tanah dan suhu tanah. Oleh sebab itu, makalah ini menyajikan model JST untuk memprediksi gas metana berdasarkan parameter lingkungan biofisik tanah yang mudah diukur yaitu kelembaban tanah, suhu tanah, dan DHL tanah. 
Ketiga parameter lingkungan biofisik tersebut diukur menggunakan satu jenis sensor secara kontinu.

Adapun tujuan dari makalah ini adalah: 1) mengembangkan model JST untuk memprediksi emisi gas metana berdasarkan parameter lingkungan biofisik yang terdiri atas kelembaban tanah, suhu tanah, dan DHL tanah; 2) memverikasi model JST yang dikembangkan dengan data pengukuran; dan 3) menganalisis karakteristik perubahan emisi gas metana terhadap perubahan dinamis parameter lingkungan biofisiknya.

\section{METODE}

\section{Percobaan Lapang}

Model JST yang dikembangkan berdasarkan percobaan di dua tempat yang berbeda. Di dua tempat tersebut, budidaya padi sawah dilakukan pada skala percobaan menggunakan pot untuk mempermudah pengaturan airnya. Percobaan pertama dilakukan di greenhouse Meiji University, Kanagawa Jepang dari 4 Juni sampai 21 September 2012, sedangkan percobaan kedua di laboratorium Teknik Sumberdaya Air, Departemen Teknik Sipil dan Lingkungan dari 2 Juli sampai 10 Oktober 2014 (Gambar 1). Di kedua lokasi tersebut, budidaya SRI diterapkan dengan menggunakan benih muda dan tanam tunggal.

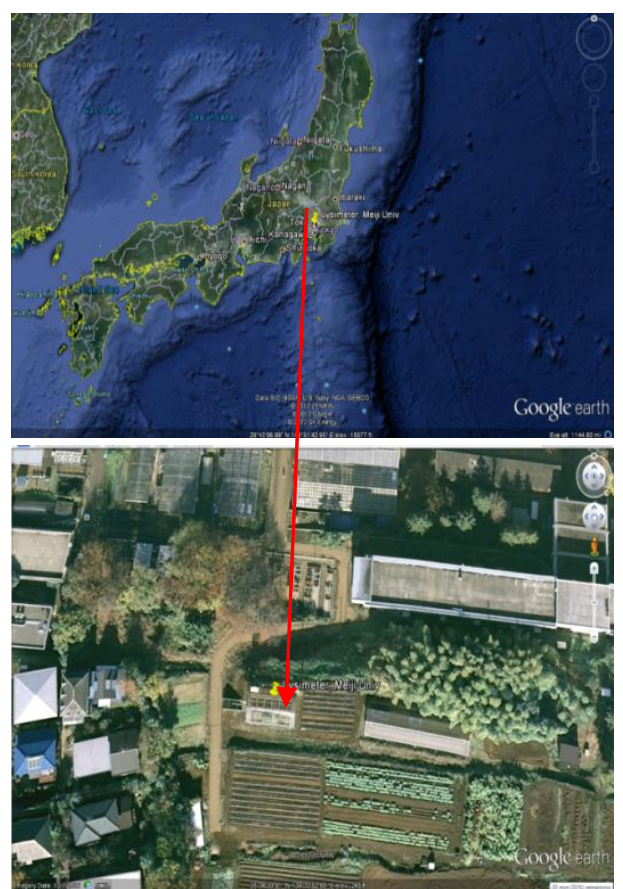

(a)

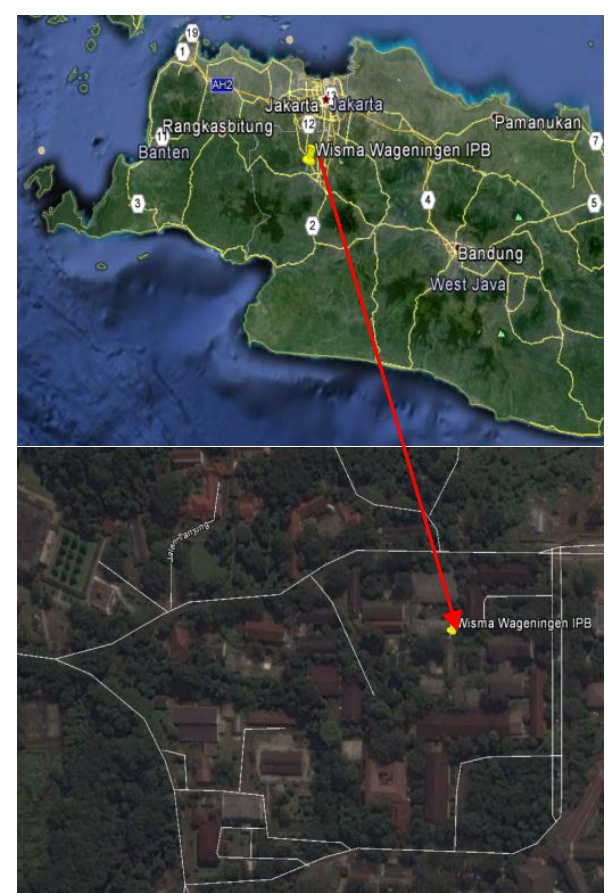

(b)

Gambar 1 Lokasi percobaan budidaya padi sawah di pot

Untuk percobaan di lokasi pertama dan kedua, terdapat tiga perlakuan pemberian air yang berbeda setelah tanaman berumur 20 hari setelah tanam (HST). Ketiga perlakuan tersebut adalah SRI basah, SRI sedang, dan SRI kering. Untuk lokasi pertama, SRI basah (SRI B1) diperoleh dengan menjaga ketinggian muka air di permukaan tanah, SRI sedang dan kering (SRI S1 dan SRI K1), ketinggian muka air dijaga pada ketinggian berturut-turut $5 \mathrm{~cm}$ dan $10 \mathrm{~cm}$ di bawah permukaan tanah. Sedangkan untuk percobaan di lokasi kedua, SRI basah (SRI B2) juga diperoleh dengan menjaga ketinggian muka air di permukaan tanah. Untuk SRI sedang (SRI S2) diperoleh dengan menjaga ketinggian muka air $3 \mathrm{~cm}$ di bawah permukaan tanah. Sedangkan untuk SRI kering (SRI K2) diperoleh juga dengan menjaga ketinggian muka air $10 \mathrm{~cm}$ di bawah permukaan tanah sama seperti SRI K1 (Gambar 2). 


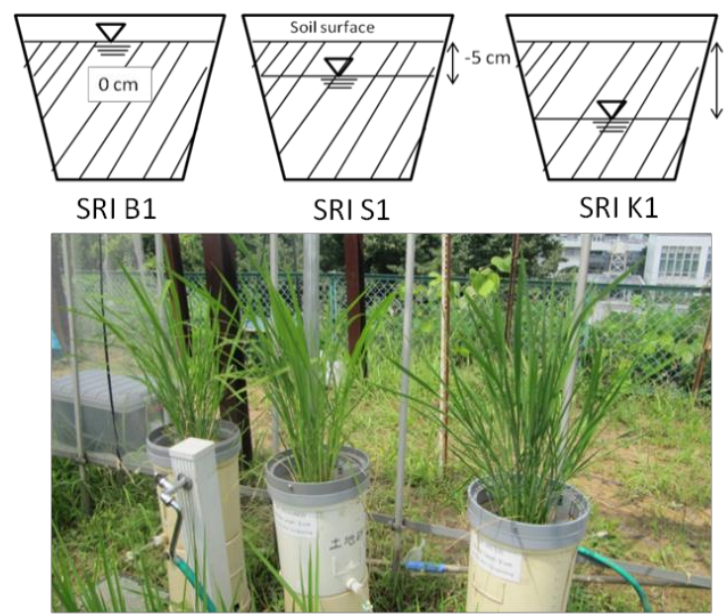

a
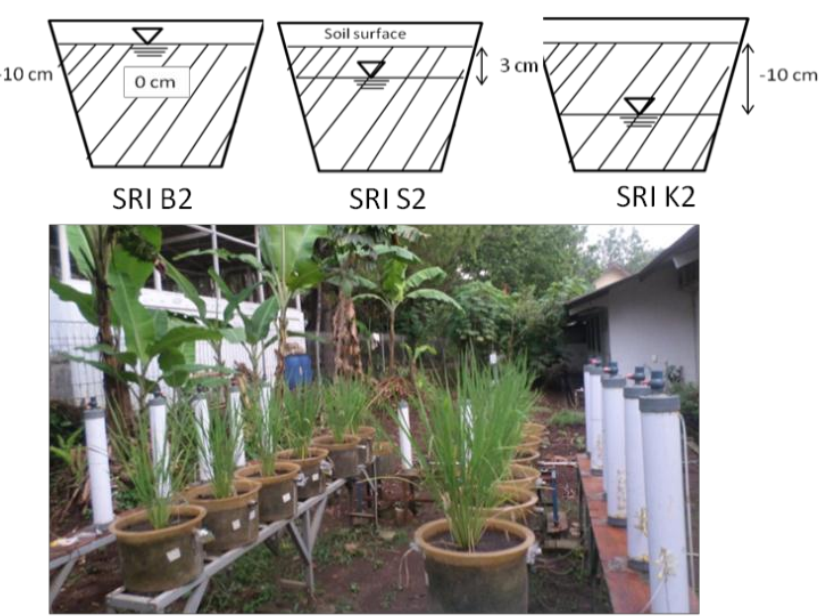

b

Gambar 2 Perlakuan pemberian air irigasi pada masing-masing percobaan

Untuk pengukuran parameter lingkungan biofisik di tanah, sensor 5-TE yang dapat mengukur kelembaban tanah, suhu tanah, dan DHL tanah sekaligus dipasang pada kedalaman $5 \mathrm{~cm}$ di bawah permukaan tanah dengan interval 30 menit secara kontinu. Sedangkan emisi gas metana diukur dengan melakukan sampling gas menggunakan boks tertutup yang dipasang di masing-masing pot. Boks tertutup tersebut memiliki diameter $30 \mathrm{~cm}$ dengan tinggi $100 \mathrm{~cm}$. Sampling gas tersebut kemudian dibawa ke lab untuk dianalisis menggunakan gas chromatography. Pengukuran gas metana tersebut hanya dilakukan di lokasi pertama karena keterbatasan alat analisis gas di lokasi kedua. Untuk lokasi kedua, gas metana pada masing-masing percobaan akan diprediksi dengan menggunakan model JST yang telah dikembangkan.

Pada waktu pengambilan sampling gas, boks tertutup diletakkan pada pot yang telah ditanami padi. Sampling gas diambil empat kali setiap 10 menit mulai dari menit ke-0 sampai menit ke30. Fluks dari keempat sampling gas tersebut kemudian ditentukan untuk mengetahui peningkatan atau penurunan konsentrasi gas metana di dalamnya. Apabila fluks bernilai positif, maka emisi gas metana terjadi dan sebaliknya. Total emisi selama periode tanam dihitung dengan menggunakan metode numerik Simpson dengan persamaan berikut dengan $a$ dan $b$ merupakan waktu pengukuran sampling gas (hst).

$$
\int_{a}^{b} f(x) d x \approx \frac{b-a}{6}\left[f(a)+4 f\left(\frac{a+b}{2}\right)+f(b)\right]
$$

\section{Pengembangan Model}

Model JST yang dikembangkan terdiri dari 3 layer, yaitu masukan (input layer), tersembunyi (hidden layer), dan keluaran (output layer). Untuk layer masukan terdiri atas 3 node: kelembaban tanah, suhu tanah, dan DHL tanah; sedangkan gas metana dijadikan keluaran dari model tersebut (Gambar 3). Tiap layer terhubung dengan nilai pembobot (weights). Algoritma back propagation digunakan untuk pembelajaran model. Algoritma ini terdiri atas dua fase, yaitu perhitungan maju dan mundur (forward and backward propagation) dan update pembobot. Fungsi sigmoid digunakan sebagai fungsi aktivasi sebagai berikut:

$$
\begin{aligned}
& \mathrm{f}(y)=\frac{1}{1+\mathrm{e}^{-g y}} \\
& y=\sum_{i=0}^{n} x_{i} w_{i}
\end{aligned}
$$


dengan $x_{i}, w_{i}, n$, dan $g$ berturut-turut adalah data masukan, pembobot, jumlah noda masukan, dan konstanta aktivasi.

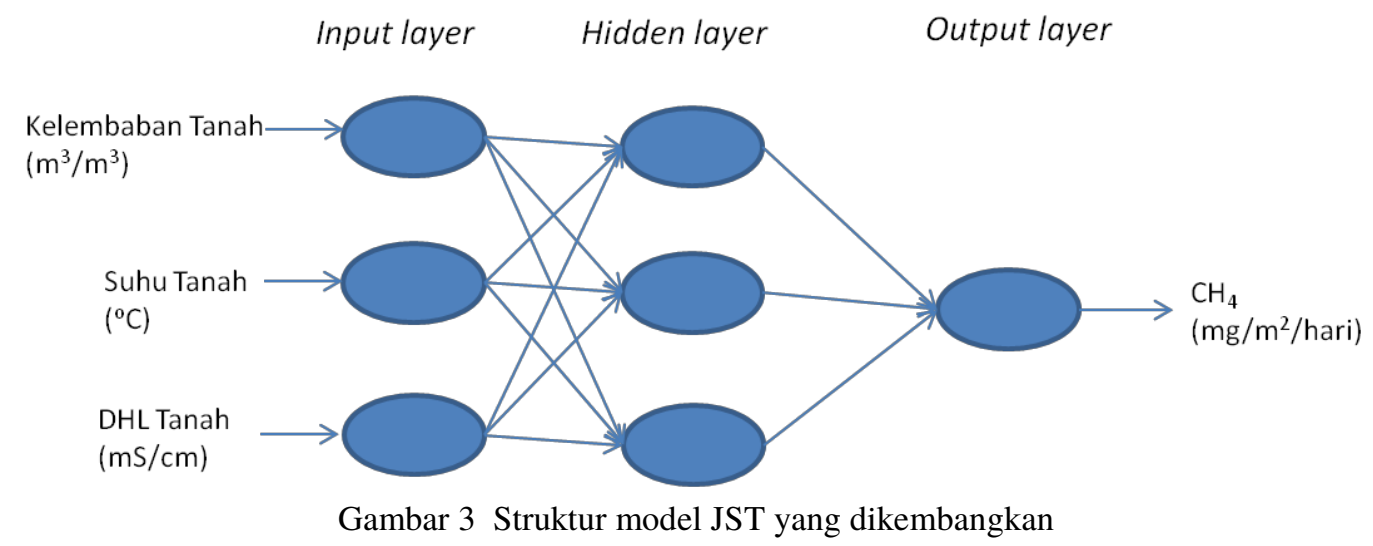

Model JST tersebut dikembangkan dalam Microsoft Excel 2007 dengan fasilitas Visual Basic for Applications (VBA). Kinerja dari model JST diukur dengan membandingkan nilai emisi gas metana hasil pengukuran dan prediksi dengan melihat nilai koefisien determinasi $\left(R^{2}\right)$ yang bernilai antara $0-1$. Apabila nilai $R^{2}$ semakin besar dan mendekati 1 maka model JST yang dikembangkan dapat digunakan untuk memprediksi emisi gas metana dari padi sawah.

\section{HASIL DAN PEMBAHASAN}

\section{Emisi Gas Metana pada Kondisi Lingkungan Biofisik Tanah yang Berbeda}

Emisi gas metana dari padi sawah terjadi secara dinamis dan dipengaruhi oleh banyak faktor termasuk kondisi lingkungan biofisik tanah. Gambar 4 menunjukkan hubungan antara emisi gas metana dengan parameter lingkungan biofisik tanah yang meliputi kelembaban tanah, suhu tanah dan DHL tanah. Dari Gambar 4 terlihat hubungan yang tidak linear antara emisi gas metana dengan kelembaban tanah, suhu tanah, dan DHL tanah dengan indikasi nilai $R^{2}$ yang cukup kecil $(<0.33)$.

Meskipun demikian, apabila dilihat tren hubungan antara emisi gas metana dengan parameter lingkungan biofisik tersebut terlihat bahwa emisi gas metana meningkat seiring dengan peningkatan kelembaban tanah, suhu tanah, dan DHL tanah. Emisi gas metana cukup tinggi ketika kelembaban tanah berkisar antara 45-50\%. Hal ini mengindikasikan bahwa semakin lembab dan basah kondisi tanah, maka emisi gas metana akan meningkat. Oleh sebab itu, kondisi sawah tergenang dengan kelembaban tanah yang tinggi bahkan dalam kondisi jenuh memiliki potensi besar untuk mengemisikan gas metana. Untuk suhu tanah, emisi gas metana cukup tinggi ketika suhu tanah berkisar antara $25-30{ }^{\circ} \mathrm{C}$. Suhu tanah memegang peranan penting dalam aktifitas mikroorganisme tanah. Sebagian besar bakteri metanaogenik (bakteri penghasil gas metana) merupakan bakteri mesofilik yang berkerja optimum pada suhu minimum $30{ }^{\circ} \mathrm{C}$ (Vogels et al. 1988). Sedangkan DHL tanah, nilai maksimum emisi gas metana terjadi ketika nilai DHL tanah berkisar antara $0.3-0.4 \mathrm{mS} / \mathrm{cm}$.

\section{Prediksi Emisi Gas Metana dengan Model JST}

Data yang digunakan untuk proses pembelajaran model JST adalah data dari hasil pengukuran gas metana pada percobaan di lokasi pertama untuk seluruh perlakuan pemberian air, baik itu SRI B1, S1, maupun K1. Pembelajaran model dilakukan sebanyak 20000 pengulangan untuk meng-update nilai pembobot. Hasil dari pembelajaran tersebut dapat dilihat pada Gambar 5 berikut ini. 

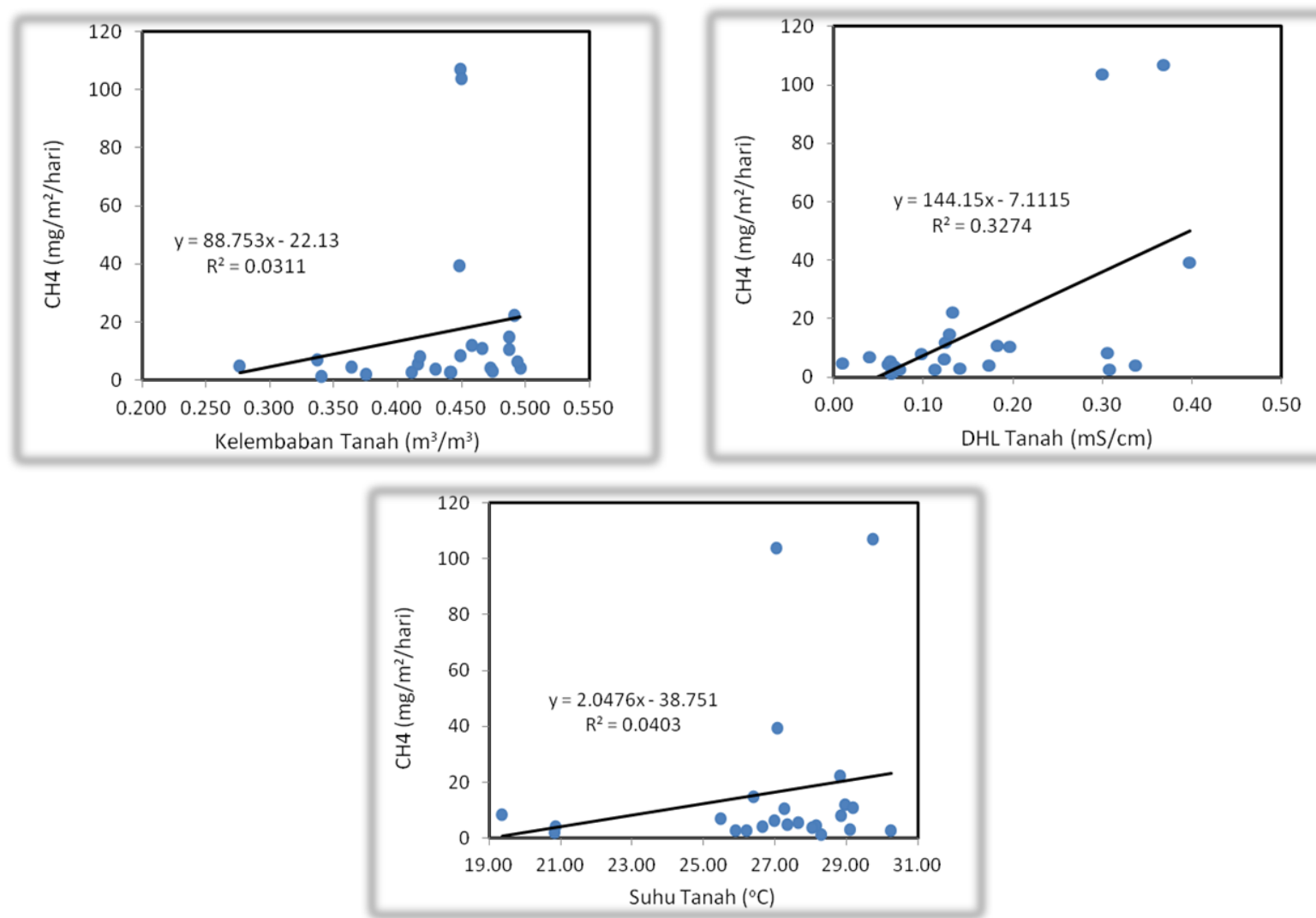

Gambar 4 Hubungan linear antara emisi gas metana dengan parameter lingkungan biofisik di dalam tanah

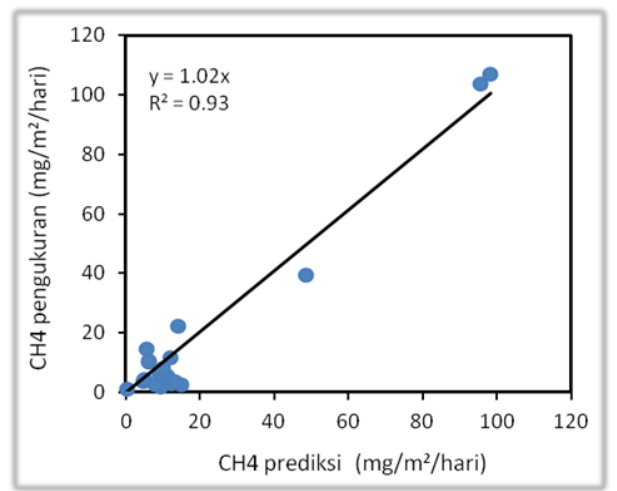

(a)

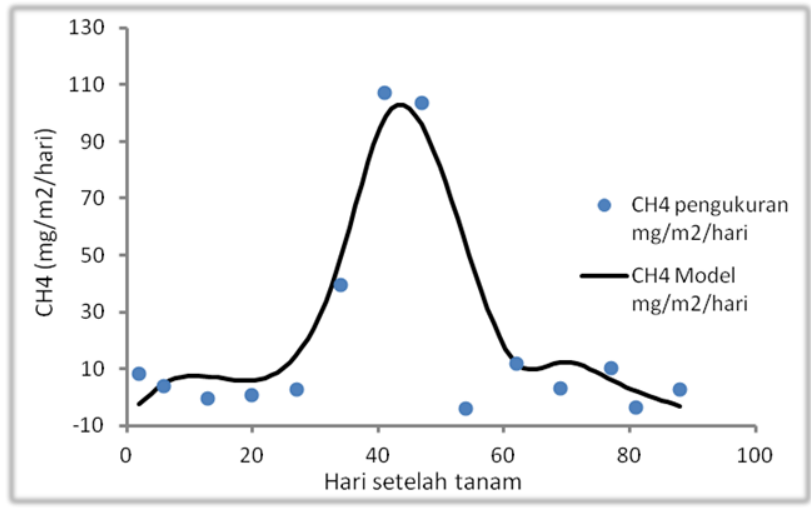

(b)

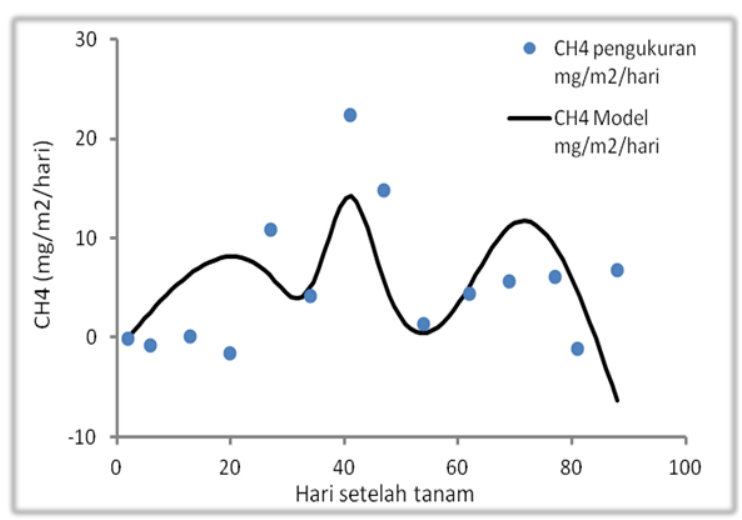

(c)

Gambar 5 (a) Hasil validasi model JST, (b) perbandingan antara emisi gas metana hasil pengukuran dengan prediksi untuk SRI B1, dan (c) perbandingan antara emisi gas metana hasil pengukuran dengan prediksi untuk SRI S1 


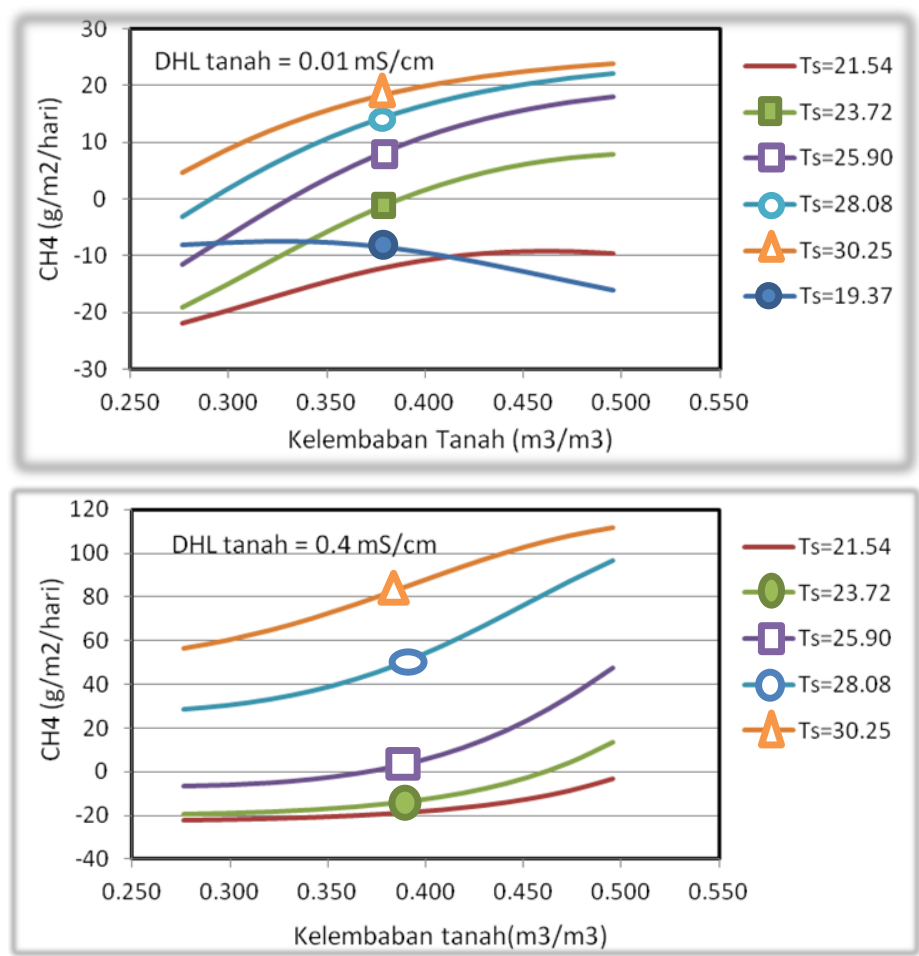

Gambar 6 Karakteristik emisi gas metana pada kondisi kelembaban tanah, suhu tanah $\left(T_{s}\right)$, dan DHL tanah yang berbeda

Gambar 5a menunjukkan bahwa model JST mampu mempelajari hubungan antara perubahan kondisi kelembaban tanah, suhu tanah, dan DHL tanah dengan emisi gas metana yang dihasilkan dari padi sawah dengan baik yang diindikasikan dengan nilai $R^{2}$ mendekati 1 . Dari hasil pembelajaran tersebut, interpolasi dilakukan terhadap hasil prediksi gas metana untuk membandingkan tren antara emisi gas metana hasil pengukuran dengan hasil prediksi model selama satu musim tanam. Hasil dari interpolasi model tersebut dapat dilihat pada Gambar 5b dan 5c. Dari gambar terlihat bahwa garis emisi gas metana hasil prediksi model mendekati poin-poin emisi gas metana hasil pengukuran. Hal ini menunjukkan bahwa tren hasil prediksi model JST sama dengan hasil pengukuran. Sehingga model JST akurat dalam memprediksi emisi gas metana.

Pembobot yang dihasilkan oleh model JST kemudian digunakan untuk menganalisis karakteristik emisi gas metana terhadap perubahan kelembaban tanah, suhu tanah, dan DHL tanah seperti terlihat di Gambar 6. Emisi gas metana meningkat seiiring dengan peningkatan kelembaban tanah sebagaimana juga telah dijelaskan pada subbab sebelumnya. Emisi gas metana meningkat tajam ketika ada kenaikan kelembaban tanah dari 27-45\%. Peningkatan kelembaban tanah biasanya dibarengi dengan pengurangan konsentrasi oksigen di dalam tanah yang diindikasikan dengan berkurangnya nilai redoks potensial tanah $\left(E_{h}\right)$ (Setyanto et al. 2000). Pengurangan oksigen tersebut menyebabkan aktivitas bakteri metanotropik yang menyerap gas metana menjadi terhambat sehingga emisi gas metana meningkat. Peningkatan suhu tanah juga mengakibatkan kenaikan emisi gas metana yang cukup signifikan. Emisi gas metana hanya menurun ketika suhu tanah lebih rendah dari $20{ }^{\circ} \mathrm{C}$. Sebaliknya setelah suhu tanah meningkat dari $20{ }^{\circ} \mathrm{C}$ sampai $30{ }^{\circ} \mathrm{C}$, emisi gas metana meningkat pesat. Hal ini sejalan dengan penelitian yang dilakukan oleh Holzapfel-Pschorn dan Seller (1986) bahwa emisi gas metana dari lahan padi sawah meningkat dua kali lipat dari suhu $20{ }^{\circ} \mathrm{C}$ menjadi $25{ }^{\circ} \mathrm{C}$. Peningkatan suhu tersebut dibarengi dengan peningkatan aktivitas mikroorganisme khususnya bakteri metanogenik. Hal ini mengindikasikan bahwa suhu tanah sangat mempengaruhi metabolisme mikroorganisme di dalam tanah. Peningkatan emisi gas metana juga terjadi ketika terjadi peningkatan DHL tanah dari 0.01 sampai $0.4 \mathrm{mS} / \mathrm{cm}$. 
Tabel 1 Perbandingan total emisi gas metana pada masingmasing perlakuan

\begin{tabular}{lcc}
\hline \multirow{2}{*}{ Perlakuan } & \multicolumn{2}{c}{ Total emisi metana $(\mathrm{kg} / \mathrm{ha} / \mathrm{musim})$} \\
\cline { 2 - 3 } & Pengukuran & Model \\
\hline SRI B1 & 18.32 & 24.42 \\
SRI S1 & 4.68 & 5.18 \\
SRI K1 & -0.56 & 3.71 \\
SRI B2 & - & 38.79 \\
SRI S2 & - & 35.77 \\
SRI K2 & - & 8.64 \\
\hline
\end{tabular}

Total emisi gas metana untuk setiap perlakuan di kedua lokasi dapat dilihat pada Tabel 1. Total hasil prediksi emisi gas metana pada perlakuan SRI B1, S1, dan K1 mendekati hasil pengukuran dengan nilai $R^{2}$ sebesar 0.96 . Hal ini semakin menguatkan bahwa model JST dapat digunakan untuk memprediksi emisi gas metana dari padi sawah. Perlakuan SRI B1 mengemisikan gas metana tertinggi di lokasi pertama, sedangkan SRI B2 menghasilkan emisi terbesar di lokasi kedua. Hal ini menunjukkan bahwa semakin tinggi muka air tanah di pot, maka semakin besar emisi gas metana yang akan dihasilkan. Sebaliknya, SRI K1 dan K2 menghasilkan emisi terendah ketika tinggi muka air paling rendah di bawah permukaan tanah. Untuk itu, hasil ini semakin menguatkan bahwa perlakuan air irigasi di lahan padi sawah dapat dijadikan pilihan mitigasi gas rumah kaca.

\section{SIMPULAN}

Model jaringan syaraf tiruan (JST) dapat digunakan untuk memprediksi emisi gas metana dari padi sawah dengan baik berdasarkan data lingkungan biofisik tanah seperti kelembaban tanah, suhu tanah dan DHL tanah. Hasil proses pembelajaran model JST menghasilkan nilai $\mathrm{R}^{2}$ sebesar 0.93 yang mengindikasikan bahwa model yang telah dikembangkan ini dapat diterima. Dari model tersebut, analisis karakteristik emisi gas metana terhadap perubahan dinamis kelembaban tanah, suhu tanah dan DHL tanah dapat dilakukan dengan baik juga. Hasilnya menunjukkan bahwa emisi gas metana semakin meningkat seiring dengan peningkatan kelembaban tanah, suhu tanah dan DHL tanah. Sebagai saran pengembangan model ini, diperlukan lebih banyak data pengukuran emisi gas metana pada interval kelembaban tanah, suhu tanah dan DHL tanah yang lebih besar.

\section{UCAPAN TERIMA KASIH}

Terima kasih disampaikan kepada Direktorat Pendidikan Tinggi yang telah mendanai riset ini melalui skema Penelitian Bagi Pendidikan Magister Menuju Doktor untuk Sarjana Unggul tahun 2014. Kami juga menyampaikan terima kasih kepada Prof Kesuke Noborio dan mahasiswa beliau dari Meiji University yang telah mengizinkan dan membantu penulis melakukan riset di tempat mereka.

\section{DAFTAR PUSTAKA}

Basheer IA, Harmeer M. 2000. Artificial neural networks: fundamentals, computing, design, and application. J Microbiol Methods. 43: 3-31.

Hashimoto Y. 1997. Application artificial neural network and genetic algorithms to agricultural system. Computer and Electronics in Agriculture. 18: 71-72. 
Hinnell AC, Lazarovitch N, Furman A, Poulton M, Warrick AW. 2009. Neuro-drip: estimation of subsurface wetting patterns for drip irrigation using neural networks. Irrig Sci. 28(6): 535-544.

Holzapfel-Pschorn A, Seiler W. 1986. Methane emission during a cultivation period from an Italian rice paddy. J Geophys Res. 91(11): 803-814.

Rajakishore SK, Doraisamy P, Subramanian KS, Maheswari M. 2013. Methane emission patterns and their associated soil microflora with SRI and conventional systems of rice cultivation in Tamil Nadu, India. Taiwan Water Conservancy. 61(4): 126-134.

Raju SK, Kumar DN, Duck L. 2006. Artificial neural networks and multicriterion analysis for sustainable irrigation planning. Comput Oper Res. 33(4): 1138-1153.

Setiawan BI, Irmansyah A, Arif C, Watanabe T, Mizoguchi M, Kato H. 2013. Effects of groundwater level on $\mathrm{CH}_{4}$ and $\mathrm{N}_{2} \mathrm{O}$ emissions under SRI paddy management in Indonesia. Taiwan Water Conservancy. 61(4): 135-146.

Setyanto P, Makarim AK, Fagi AM, Wassman R, Buendia LV. 2000. Crop management affecting methane emissions from irrigated and rainfed rice in Central Java (Indonesia). Nutr Cycl Agroecosys. 58: 85-93.

Snyder CS, Bruulsema TW, Jensen TL. 2007. Best management practices to minimize greenhouse gas emissions associated with fertilizer use. Better Crops. 19: 16 -18.

Vogels GD, Keltjen JT, Van der Drift C. 1988. Biochemistry of methane production biology of and aerobic microorganisms. Nature. 350: 406-409. 